\title{
Perbandingan Chula Formula dengan Auskultasi 5 Titik terhadap Kedalaman Optimal Pipa Endotracheal pada Anestesi Umum di RSUP Dr. Hasan Sadikin Bandung
}

\author{
Erick Ariestian, ${ }^{1}$ Iwan Fuadi, ${ }^{2}$ Tinni T. Maskoen ${ }^{2}$ \\ ${ }^{1}$ Rumah Sakit Umum Daerah Dr. Rubini Mempawah, Kalimantan Barat, \\ ${ }^{2}$ Departemen Anestesiologi dan Terapi Intensif \\ Fakultas Kedokteran Universitas Padjadjaran/RSUP Dr. Hasan Sadikin Bandung
}

\begin{abstract}
Abstrak
Kedalaman pipa endotracheal (ETT) yang optimal menjadi salah satu perhatian utama karena komplikasi terkait dengan malposisi ETT. Auskultasi 5 titik merupakan metode yang digunakan dalam menentukan kedalaman ETT. Namun, teknik tersebut masih memiliki potensi malposisi ETT. Penggunaan chula formula terbukti dapat digunakan untuk menentukan kedalaman ETT yang optimal. Penelitian ini bermaksud menilai ketepatan kedalaman yang optimal penempatan ETT setelah dilakukan intubasi endotrakea menggunakan chula formula dibanding dengan tektik auskultasi 5 titik. Penelitian ini merupakan penelitian prospektif analitik komparatif yang dilakukan pada 48 orang pasien berusia $\geq 18$ tahun, status fisik American Society of Anesthesiology (ASA) I-II di ruang bedah terjadwal RSUP Dr. Hasan Sadikin Bandung pada Oktober 2017. Subjek dibagi menjadi 2 kelompok perlakuan, yaitu kelompok penentuan kedalaman ETT menggunakan teknik auskultasi 5 titik dan kelompokyang dilakukan menggunakan chula formula. Dilakukan penilaian jarak ujung ETT terhadap carina menggunakan fiberoptic bronchoscope (FOB). Hasil penelitian ini menunjukkan kedalaman optimal ETT menggunakan chula formula lebih baik dibanding dengan teknik auskultasi 5 titik. Analisis statistik menggunakan uji Exact Fisher. Hasil analisis menunjukkan perbedaan signifikan secara statistik $(\mathrm{p}<0,05)$. Simpulan penelitian ini adalah penggunaan chula formula menghasilkan kedalaman ETT yang lebih optimal.
\end{abstract}

Kata kunci: Auskultasi 5 titik, bronkoskopi fiberoptik, chula formula, intubasi endotrakea, kedalaman ETT

\section{Comparison between Chula Formula and 5 Points Auscultation for Optimal Endotracheal Tube Depth in General Anesthesia in Dr. Hasan Sadikin General Hospital Bandung}

\begin{abstract}
The optimal depth of the endotracheal tube (ETT) becomes one of the major concerns due to complications associated with ETT malposition. The 5 point auscultation is a method that has been used in determining ETT placement in intubated patients. However, this technique has the potential for causing ETT malposition. Chula formula has been proven to be used for determining the optimal depth of ETT placement. The aim of this study was to assess the accuracy of the optimal depth for ETT placement after endotracheal intubation using Chula formula compared to the 5 point auscultation technique. This was a prospective analytical comparative study involving 48 patients aged $\geq 18$ years old with ASA I-II physical status who underwent elective surgery at Dr. Hasan Sadikin General Hospital in October 2017. Subjects was divided into 2 groups. The first group received the 5 point auscultation technique to determine the depth of ETT while the Chula formula was used in the second group. The distance between the tip of ETT to carina was evaluated using fiberoptic bronchoscope (FOB). This study showed that the depth of ETT was better in patients who received Chula formula technique compared to those who received the 5 point auscultation technique. Statistical analysis using Exact Fisher test showed significant differences between the 2 groups $(\mathrm{p}<0.05)$. Therefore, Chula formula is able to provide optimum ETT depth.
\end{abstract}

Key words: Five point auscultation, chula formula, depth of ETT, endotracheal intubation, fiberoptic bronchoscope

Korespondensi: Erick Ariestian, dr., SpAn, Rumah Sakit Umum Daerah Dr. Rubini Mempawah,Jl. Raden Kusno, Kelurahan Terusan, Kecamatan Mempawah Hilir, Kabupaten Mempawah, Provinsi Kalimantan Barat, Email andynakamura@gmail. com 


\section{Pendahuluan}

Intubasi endotrakea adalah salah satu prosedur penting dan umum untuk mengamankan jalan napas, pengobatan darurat, dan perawatan kritis. ${ }^{1}$ Salah satu perhatian utama untuk mengamankan ETT adalah kedalaman yang optimal karena komplikasi terkait malposisi ETT. $^{2,3}$ Penempatan yang terlalu dalam dapat menyebabkan ETT menyentuh carina sehingga menstimulasi respons simpatis dan menyebabkan takikardia, hipertensi, atau spasme bronkus. Intubasi endobronkial juga dapat mengakibatkan hiperinflasi paru sehingga meningkatkan risiko pneumotoraks. Penempatan yang terlalu dangkal dapat menyebabkan ETT terlalu dekat dengan pita suara sehingga balon ETT menekan pita suara dan menyebabkan trauma pita suara, kompresi saraf laryngeal recurrent, serta meningkatkan risiko terlepasnya ETT. ${ }^{3,4}$

Posisi ETT yang optimal adalah posisi ujung balon proksimal ETT berada $2 \mathrm{~cm}$ di bawah pita suara, sedangkan ujung distal ETT berada pada $2-4 \mathrm{~cm}$ dari carina. ${ }^{5} \mathrm{Hal}$ ini dimaksudkan untuk mencegah ekstubasi secara tidak sengaja dan intubasi endobronkial. Teknik umum untuk mengetahui posisi ETT setelah dilakukan intubasi adalah dengan cara auskultasi 5 titik karena mudah dalam melakukannya. Auskultasi 5 adalah auskultasi 2 titik di setiap sisi dada dan 1 titik di daerah epigastrium. ${ }^{1,2}$

Sebuah penelitian membuktikan bahwa penggunaan auskultasi untuk membedakan antara intubasi endotrakea dan endobronkial tidak dapat diandalkan dengan sensitivitas sebesar 65\% dan spesifisitas 59\%. ${ }^{6}$ Pada penelitian lainnya ditemukan bahwa konfirmasi kedalaman ETT dengan auskultasi 5 titik mengalami kejadian malposisi ETT sebesar 20\% dari seluruh kasus intubasi endotrakea, terdapat $15 \%$ kasus di antaranya ditemukan ujung ETT berada kurang dari $2 \mathrm{~cm}$ di atas carina, 5\% kasus lain berada pada cabang utama bronkus. ${ }^{7}$ Fiberoptic bronchoscope adalah cara yang paling pasti untuk mengonfirmasi penempatan ujung ETT karena memberi visualisasi secara jelas.
Penelitian penggunaan FOB sebagai tambahan untuk pendekatan terhadap verifikasi ETT ${ }^{4,8}$

Penelitian pada tahun 2005 menunjukkan bahwa tinggi badan mempunyai hubungan terhadap kedalaman optimal ETT, dari hubungan tersebut dirumuskan menjadi sebuah rumus yang disebut dengan chula formula (tinggi dalam cm: 10+4). Dalam penelitian tersebut penggunaan chula formula memberikan hasil letak ujung ETT paling sedikit $2 \mathrm{~cm}$ di atas carina yang dikonfirmasi dengan menggunakan FOB. ${ }^{2,9}$

Penelitian ini bertujuan mengetahui kedalaman optimal ETT setelah dilakukan intubasi endotrakea menggunakan teknik chula formula dibanding dengan auskultasi 5 titik yang dilakukan oleh tenaga medis yang terlatih.

\section{Subjek dan Metode}

Penelitian ini merupakan penelitian uji analitik komparatif prospektif mengenai kedalaman optimal ETT setelah intubasi endotrakea pada semua pasien yang akan menjalani operasi elektif dengan teknik anestesi umum menggunakan teknik chula formula dibanding dengan auskultasi 5 titik di Central Operating Theater (COT) lantai 3 dan 4 di RSUP Dr. Hasan Sadikin (RSHS) Bandung. Penelitian dilakukan pada bulan Oktober 2017.

Kriteria inklusi dari subjek penelitian ini adalah pasien dengan status fisik American Society of Anesthesiologist (ASA) I dan II, usia $\geq 18$ tahun. Kriteria eksklusi, yaitu massa pada daerah leher yang diduga mengubah struktur anatomi jalan napas dan dibuktikan dengan hasil $x$-ray soft tissue leher (STL) dan tidak dapat dilakukan auskultasi 5 titik. Kriteria pengeluaran pasien dengan kelainan anatomi jalan napas yang tidak ditemukan saat pemeriksaan preoperatif, pasien mengalami desaturasi oksigen dan pasien mengalami kesulitan intubasi. Penentuan besar sampel dilakukan berdasar atas perhitungan statistik dengan menetapkan taraf kepercayaan 95\% dan kuasa uji (power test) 90\%. Penentuan besar sampel menggunakan rumus untuk penelitian analitis kategorik numerik tidak 
berpasangan. Pemilihan subjek penelitian berdasar atas consecutive sampling, yaitu mengambil setiap subjek penelitian yang memenuhi kriteria inklusi dan tidak termasuk kriteria eksklusi berdasar atas urutan kedatangan pasien. Subjek penelitian terdiri atas 48 pasien. Dilakukan randomisasi urutan penggunaan teknik untuk mengetahui kedalaman optimal ETT setelah dilakukan intubasi endotrakea.

Penelitian dilakukan setelah mendapatkan persetujuan Komite Etik Penelitian Kesehatan Fakultas Kedokteran Universitas Padjadjaran/ RSHS. Operator penelitian akan mendapatkan penjelasan secara verbal dan demonstrasi mengenai intubasi endotrakea. Tinggi badan pasien didapatkan dari catatan rekam medis pasien dan dilakukan perhitungan kedalaman optimal ETT menggunakan rumus pada kelompok chula formula. Subjek penelitian terdiri atas 48 pasien yang dibagi dalam 2 kelompok. Kelompok pertama adalah auskultasi 5 titik, selanjutnya peneliti melakukan pengukuran menggunakan FOB. Kelompok kedua adalah kelompok yang melakukan intubasi endotrakea dengan chula formula, kemudian peneliti melakukan pengukuran menggunakan FOB. Pengambilan data hasil penelitian berupa kedalaman ETT setelah intubasi endotrakea.

Pengukuran jarak ujung ETT terhadap carina dilakukan dengan cara memasukkan FOB ke dalam ETT. Sebuah pita perekat kertas yang sudah ditambahkan angka pengukuran dalam satuan sentimeter $(\mathrm{cm})$ ditempelkan pada titik nol yang ditentukan pada FOB. Titik nol ditentukan dengan cara memasukkan FOB hingga ujung distal ETT. Ujung proximal ETT tersebut menjadi penentu titik nol. Selanjutnya, FOB dimasukkan melalui ETT hingga ujung FOB menyentuh carina. Angka yang berpotongan dengan ujung proksimal ETT dianggap sebagai jarak carina terhadap ujung proksimal ETT (Gambar 1). Kedalaman

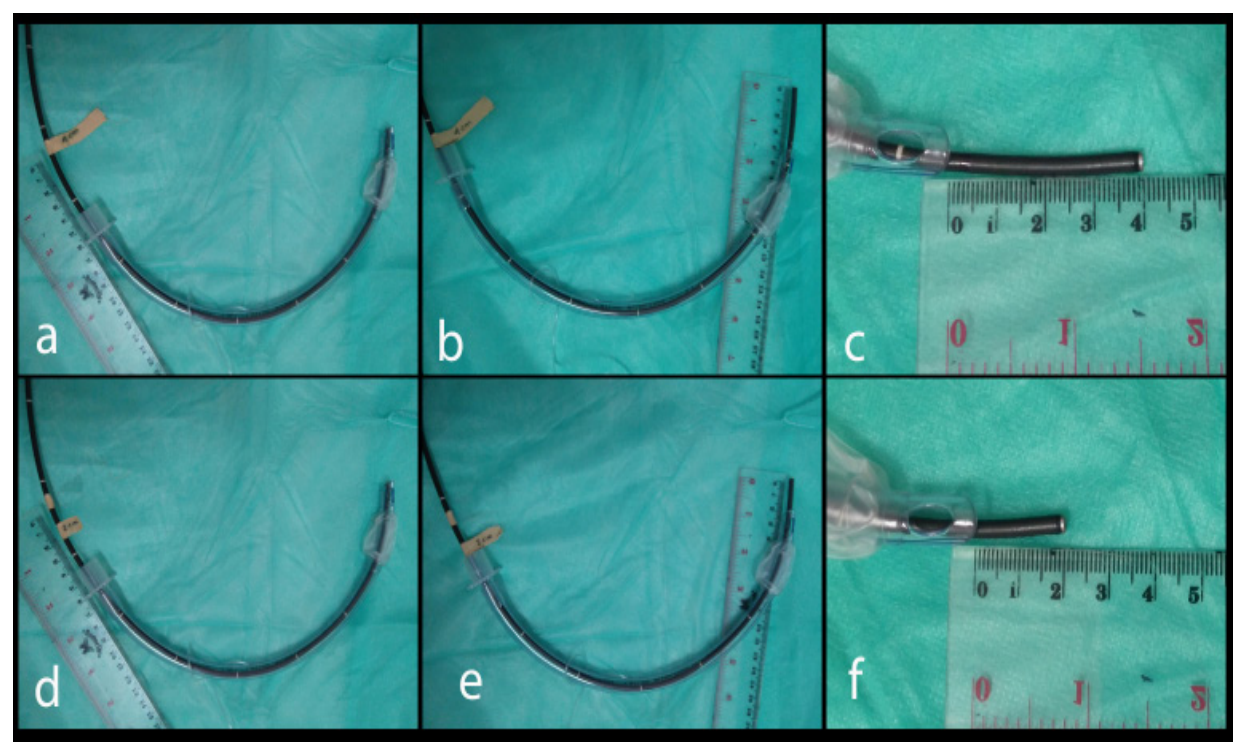

\section{Gambar 1 Metode Pengukuran Ujung ETT ke Jarak Carina}

Ket.:FiberopticbronchoscopedimasukkankedalamETThinggaujungdistal.Dilakukanpengukuran dari ujung proksimal dengan jarak $2 \mathrm{~cm}$ dan $4 \mathrm{~cm}$ ditandai dengan plester pada Gambar a dan d. Pada saat dilakukan pemeriksaan fiberoptic bronchoscope didorong sampai ujung FOB menyentuh carina posisi ETT dianggap ideal apabila ujung ETT berada pada rentang plester (2-4 cm) pada Gambar b dan e. Jarak plester tersebut menggambarkan jarak antara ujung distal ETTsampai ujung FOB pada Gambar $\mathrm{c}$ dan $\mathrm{f}$

Sumber: Dokumentasi pribadi 
Tabel Perbandingan antara Kedalaman ETT (cm) dan Jarak Carina (cm) pada Kelompok Teknik Auskultasi 5 Titik dan Teknik Chula Formula

\begin{tabular}{lccc}
\hline \multirow{2}{*}{ Variabel } & Auskultasi 5 titik & ChulaFormula & Nilai p \\
\cline { 2 - 3 } & $\mathbf{n = 2 4}$ & $\mathbf{n = 2 4}$ & \\
\hline Jarak ujung ETT ke carina $(\mathrm{cm})$ & & & $0,0001^{*}$ \\
Rata-rata $\pm S D$ & $2,06 \pm 1,345$ & $2,27 \pm 0,329$ & \\
Median & 1,750 & 2,000 & \\
Jarak ujung ETT ke carina $(\mathrm{cm})$ & 9 & 24 & \\
Optimal & 15 & 0 \\
Tidak optimal & \multicolumn{3}{c}{} \\
\hline
\end{tabular}

Keterangan: untuk data numerik, uji statistik dilakukan dengan Uji Mann Whitney. Untuk Data kategorik nilai p dihitung berdasar atas uji Exact Fisher. Nilai kemaknaan berdasar atas nilai p $<0,05$. Tanda* menunjukkan nilai $\mathrm{p}<0,05$ artinya signifkan atau bermakna secara statistik

ETT dianggap optimal apabila ujung distal ETT berjarak 2-4 cm di atas carina setelah dilakukannya intubasi endotrakea.

Analisis data meliputi analitik prospektif komparatif dan uji hipotesis. Data disajikan dalam bentuk persentase (\%) untuk variabel kategorik dan median untuk variabel numerik. Untuk variabel kategorik dilakukan uji Exact Fisher. Untuk variabel numerik dilakukan dengan uji Mann Whitney. Data diolah dengan program statistical product and service solution (SPSS) versi 24.0 for windows.

\section{Hasil}

Keberhasilan penentuan kedalaman optimal ETT setelah intubasi endotrakea menggunakan teknik chula formula terdapat pada seluruh sampel, sedangkan keberhasilan dengan menggunakan auskultasi 5 titik terdapat 9 dari 15. Hal ini menunjukkan perbedaan bermakna secara statistik ( $\mathrm{p}<0,05$; Gambar 2).

Jarak carina pada kelompok teknik auskultasi 5 titik memiliki rata-rata sebesar $2,06 \pm 1,345$, sedangkan pada teknik chula formula memiliki rata-rata sebesar $2,27 \pm 0,329$ (Tabel).

\section{Pembahasan}

Penggunaan teknik chula formula untuk menentukan kedalaman opimal ETT telah dilakukan pada penelitian sebelumnya. Kekurangan pada penelitian sebelumnya adalah terdapat perubahan posisi kepala setelah dilakukan intubasi endotrakea

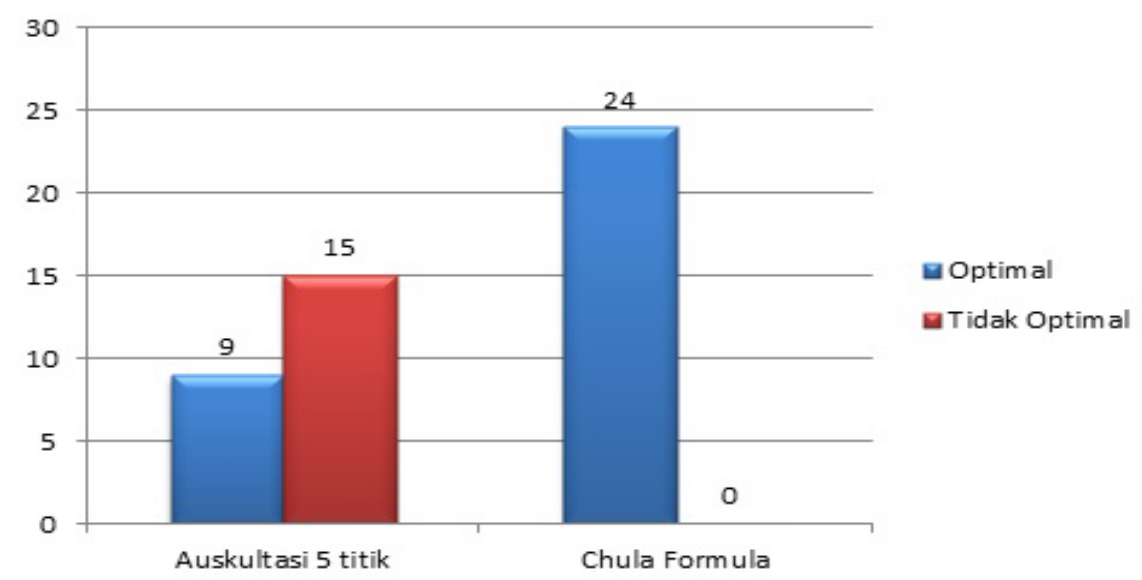

Gambar 2 Grafik Perbandingan Kedalaman Optimal ETT Menggunakan Auskultasi 5 Titik dan Chula Formula 
yang menyebabkan tergesernya ETT. Pada penelitian ini, kami membandingkan teknik chula formula dengan teknik auskultasi 5 titik untuk mengetahui kedalaman optimal ETT setelah dilakukan intubasi endotrakea. Penggunaan FOB untuk menilai kedalaman ujung ETT terhadap carina dibuat sama dengan penelitian sebelumnya, yaitu menggunakan FOB.

Pada teknik auskultasi 5 titik, tantangan yang dihadapi adalah mendengarkan suara paru yang seimbang dari kedua lapang dada setelah dilakukan intubasi endotrakea dengan posisi ujung ETT diharapkan berada pada posisi $2-4 \mathrm{~cm}$ di atas carina. Untuk menilai posisi optimal dari ujung ETT diperlukan alat bantu seperti FOB. Beberapa penelitan menunjukkan teknik auskultasi 5 titik untuk menentukan kedalaman ETT yang optimal membutuhkan latihan dan pengalaman operator. $^{10}$

Pada penelitian ini menunjukkan kedalaman optimal ETT menggunakan teknik chula formula lebih bermakna dibanding dengan teknik auskultasi 5 titik. Hal ini mungkin disebabkan oleh teknik chula formula yang menggunakan tinggi badan subjek berhubungan dengan panjang trakea dan kedalaman optimal ETT setelah intubasi endotrakea. Hal yang sama juga diperlihatkan pada beberapa penelitian lain yang menunjukkan keberhasilan intubasi endotrakea mengunakan rumus berbasis tinggi badan subjek yang lebih bermakna dibanding dengan teknik auskultasi 5 titik.

Pada penelitian yang dilakukan pada tahun 1989 dirumuskan perhitungan kedalaman ETT yang optimal berdasar atas tinggi badan pada populasi barat dengan rumus: tinggi badan $(\mathrm{cm}) / 10+5$. Rumus ini optimal digunakan pada populasi barat. Pada penelitian yang lain di tahun 2016 dirumuskan perhitungan kedalaman ETT berdasar atas tinggi badan dengan rumus: tinggi badan $(\mathrm{cm}) / 5-13$, dan rumus ini optimal digunakan pada populasi Amerika Selatan. Penelitian ini menggunakan chula formula dikarenakan kemiripan karakter populasi masyarakat Indonesia dengan Thailand yang membuat rumus tersebut. Beberapa rumus telah diciptakan untuk memandu kedalaman optimal ETT salah satunya di Thailand yang mewakili Asia. ${ }^{2,4}$

Pada penelitian sebelumnya menunjukkan bahwa faktor gender dan berat badan tidak berpengaruh terhadap penentuan kedalaman optimal ETT. Hal ini disebabkan oleh panjang trakea hanya memiliki hubungan dengan tinggi badan. ${ }^{4}$

Pada penelitian ini subjek yang dipilih adalah pasien dewasa usia $\geq 18$ tahun. Hal ini disebabkan oleh struktur anatomi pada pasien $\leq 18$ tahun berbeda dengan struktur anatomi pasien dewasa dan juga masih mengalami pertumbuhan trakea. Perbedaan struktur anatomi, fungsi serta ukuran tersebut melibatkan kepala, hidung, lidah, epiglotis, laring, krikoid, trakea, dan bronkus utama. ${ }^{4}$

Keuntungan utama teknik chula formula adalah terdapat hubungan signifikan panjang trakea dengan tinggi badan sehingga memudahkan untuk memprediksi kedalaman optimal ETT sebelum dilakukan intubasi endotrakea dan terdapat kemiripan karakter populasi masyarakat Indonesia dengan Thailand. Pada beberapa penelitian lain dinyatakan terdapat perbedaan atau variasi kedalaman ETT dikarenakan perbedaan tinggi badan yang signifikan antara etnik Asia dan Kaukasia. Namun demikian, penggunaan teknik chula formula masih dapat diaplikasikan pada populasi masyarakat Indonesia maupun daerah Asia lain seperti Malaysia, Brunei, Kamboja, dan lainya dikarenakan kemiripan ras dan struktur anatomi salah satunya tinggi badan. ${ }^{11}$

Terdapat beberapa keterbatasan pada penelitian ini. Pertama, penelitian ini dilakukan dengan mengambil data tinggi badan dari rekam medis subjek. Keterbatasan yang kedua, penelitian ini dilakukan pembulatan angka ke atas pada jarak ujung ETT terhadap carina sehingga hasil data yang disajikan mempunyai angka yang bulat.

\section{Simpulan}

Penggunaan teknik chula formula dalam 
menentukan kedalaman optimal ETT memberikan kemudahan dan keberhasilan dibanding dengan teknik auskultasi 5 titik.

Penelitian lebih lanjut dengan jumlah sampel yang lebih besar untuk melihat kedalaman optimal ETT pada populasi masyarakat Indonesia. Peneliti menilai chula formula dapat digunakan bersama dengan auskultasi 5 titik pada praktik sehari-hari sebagai penentuan kedalaman optimal ETT pada pasien yang akan dilakukan intubasi endotrakea.

\section{Daftar Pustaka}

1. Rudraraju P, Eisen LA. Confirmation of endotracheal tube position: a narrative review. J Intens Care Med. 2009;24(5):28392.

2. Varshney M, Sharma K, Kumar R, Varshney PG. Appropriate depth of placement of oral endotracheal tube and its possible determinants in Indian adult. Indian J Anaesth. 2011;55(5):488-93.

3. Sharma K, Varshney M, Kumar R. Tracheal tube fixation: the effect on depth of insertion of midline fixation compared to the angle of the mouth. Anaesthesia. 2009;64(1):383-6.

4. Mukherjee S, Ray M, Pal R. Bedside prediction of airway length by measuring upper incisor manubrio-sternal joint length. J Anaesthesiol Clin Pharmacol. 2014;30(2):188-94.

5. Berry JM, Harvey S. Laryngoscopic orotracheal and nasotracheal intubation. Dalam: Hagberg CA, penyunting. Benumof and Hagberg's airway management. Edisi ke-3. Philadelpia: Elsevier Saunders; 2013. hlm. 346-58.

6. Ramsingh D, Frank E, Haughton R, Schiling J, Gimenez KM, Banh E, dkk. Auscultation versus point-of-care ultrasound to determine endotracheal versus bronchial intubation, a dioagnostic accuracy study. Anesthesiology. 2016;124(5):1012-20.

7. Geisser W, Maybauer DM, Wolff $\mathrm{H}$, Pfenninger E, Maybauer MO. Radiological validation of tracheal tube insertion depth in out-of-hospital and in-hospital emergency patients. Anaesthesia. 2009;64(1):973-7.

8. Collins SR, Blank RS. Fiberoptic Intubation: an overview and update. Respir Care. 2014;59(6):865-80.

9. Gomez JC, Melo LP, Orozco Y, Chicangana GA, Osori DC. Estimation of the optimum length of endotracheal tube insertion in adults. Rev Colomb Anestesiol. 2016;44(3):228-34.

10. Boucher N, Prystupa A, Witczak A, Walczak E, Dzida G, Panasiuk L. Lung auscultation - identifcation of common lung sound abnormalities and associated pathologies. J Pre-Clin Clin Res. 2013;7(1):32-5.

11. Pang G, Edward MJ, Greenland KB. Vocal cord-carina distance in anethestised Caucasian adult and its clinical implications for tracheal intubation. Anaesth Intens Care. 2010;38:1029-33. 